DOI: https://doi.org/10.47405/mjssh.v5i6.422

\begin{tabular}{|c|c|}
\hline 4 & Malaysian Journal of Social Sciences and Humanities (MJSSH) \\
\hline $\begin{array}{l}\text { Malaysian Journal of } \\
\text { Social sciences and }\end{array}$ & Volume 5, Issue 6, June 2020 \\
\hline (MJ-SSH) & e-ISSN : 2504-8562 \\
\hline & $\begin{array}{l}\text { Journal home page: } \\
\text { www.msocialsciences.com }\end{array}$ \\
\hline
\end{tabular}

\title{
Pengaruh Kejayaan Graduan Sarjana Muda Sains Pembinaan Universiti Teknologi Malaysia (UTM) dalam Kerjaya yang Diceburi
}

\author{
Mohamad Izzuan Mohd Ishar'1, Fuziah Ismail² \\ ${ }^{1}$ Sekolah Pendidikan, Fakulti Sains Sosial dan Kemanusiaan, Universiti Teknologi Malaysia (UTM) \\ 2Jabatan Ukur Bahan, Sekolah Alam Bina, Fakulti Alam Bina dan Ukur, Universiti Teknologi Malaysia (UTM) \\ Correspondence: Mohamad Izzuan Mohd Ishar (izzuanishar1991@yahoo.com)
}

\begin{abstract}
Abstrak
$\overline{\text { Faktor utama kejayaan para graduan adalah berdasarkan diri sendiri iaitu tindakan yang dilakukan oleh }}$ graduan seperti berdikari, bersikap positif dan menjaga kesihatan dalam memenuhi keperluan kerjaya yang diceburi. Melalui kerjaya juga, manusia mendapat rezeki untuk menyara hidupnya, memberi nafkah kepada orang yang berada dibawah tangunngannya dan berbakti kepada masyarakat. Melalui kajian sebelum ini, penyelidik telah menghasilkan satu laluan kerjaya bagi kursus Sarjana Muda Sains Pembinaan (SBC) Universiti Teknologi Malaysia (UTM) yang didapati melalui kaedah soal selidik para graduan SBC tahun 2007 dan 2008 agar dapat dirujuk oleh pelajar kursus ini. Sehubungan itu, kajian ini, dilakukan bagi mengenal pasti faktor kejayaan para graduan dalam bekerjaya. Seramai 15 orang graduan SBC 2007 dan 15 orang graduan SBC 2008 terlibat bagi kajian ini. Penyelidik mendapati faktor kejayaan yang dicapai akan menghasilkan kepuasan di mana kesemua 30 responden menyatakan mereka berpuas hati dengan kejayaan yang dikecapi dalam kerjaya sepanjang mereka berkerja bermula dari selepas mereka bergraduasi sehingga tahun 2013.
\end{abstract}

Kata kunci: kejayaan graduan, kerjaya, sains pembinaan

\section{Influence of Success in Bachelor of Sciences in the Construction Among the Graduates of the University of Techology Malaysia in Their Chosen Career}

\begin{abstract}
The main factor in the success of graduates is self-directed action by graduates such as self-reliance, positive attitude and health care in meeting their career requirements. Through a career, an individual also has the means to support their life, and to support the people under his care and to serve the community. Through previous research, researchers have created a career path for the Bachelor of Construction Science (SBC) Universiti Teknologi Malaysia (UTM) course which was obtained through the SBC graduate survey of 2007 and 2008 for reference by students in this course. Therefore, this study was conducted to identify the factors that make graduates succeed in their careers. A total of 15 graduates from SBC 2007 and 15 graduates from SBC 2008 were involved in this study. Researchers found the success factor to be satisfactory as all 30 respondents said they were satisfied with the success they had achieved throughout their career from their graduation until 2013.
\end{abstract}

Keywords: graduates success, career, construction science 


\section{Pengenalan}

Kerjaya merupakan sesuatu yang penting dalam kehidupan manusia. Sesetengah individu mempunyai satu pekerjaan dan sesetengah individu lagi mempunyai lebih dari satu pekerjaan dan sering bertukartukar kerjaya. Melalui pekerjaan, manusia mendapat rezeki untuk menyara hidupnya, memberi nafkah kepada orang yang bereda dibawah tangunngannya dan berbakti kepada masyarakat. Menurut Tolbert (1994) kerjaya merupakan satu rangkaian pekerjaan yang melibatkan diri seorang individu. Rangkaian kerja atau pengalaman yang dilakukan oleh seseorang dalam jangka masa yang tertentu adalah dirujuk sebagai menjalankan sebuah tanggungjawab (Rohany dan Fatimah, 1987). Selain itu, kerjaya juga meliputi persediaan sebelum seseorang itu melibatkan diri dalam pekerjaan serta peranan-peranan lain yang dilakukan selepas seseorang itu bersara. Kerjaya juga merupakan satu siri keadaan yang berlaku secara berturutan dalam kehidupan yang berkaitan dengan pemilihan kerjaya, peranan yang dimainkan serta melibatkan status seseorang itu sepanjang hayatnya (Super, 1972).

Menurut Crites (1969) pemilihan sesuatu kerjaya berlaku apabila individu tersebut menyatakan maksud serta keinginan untuk memasuki atau melibatkan diri dalam bidang kerjaya tertentu. Proses kerjaya adalah satu proses berterusan yang melibatkan diri seorang individu dalam satu siri pekerjaan yang membantu dalam perkembangan peribadi terutamanya dalam bidang kerjaya yang diceburi. Selain dari proses kerjaya, bagi Cohen (1984) kepuasan terhadap kerjaya yang diceburi dapat dikaitkan dengan penurunan kadar penyakit dari segi fizikal dan dapat meningkatkan tahap kesihatan mental. Menurut Anerbach dan Grambling (1998), kepuasan terhadap kerjaya juga akan melahirkan satu perasaan optimistik dan gembira serta satu perasaan yang boleh meningkatkan harga diri seorang individu.Melalui beberapa definisi dan penerangan berkenaan dengan kerjaya, dapat disimpulkan bahawa kerjaya merupakan satu rangkaian pekerjaan atau pengalaman yang melibatkan diri seorang individu untuk memainkan peranannya secara berturutan sepanjang hayatnya. Kerjaya juga memainkan peranan penting dalam perkembangan peribadi seseorang selepas menjalani proses kerjaya di mana seseorang itu akan mendapat kepuasan dalam pekerjaan dan kepuasan tersebut pula akan mempengaruhi kesihatan dalaman dan luarannya.

Hasil kajian yang dijalankan oleh Mohd Ishar dan Ismail (2019) terhadap laluan kerjaya graduan Sarjana Muda Sains Pembinaan Universiti Teknologi Malaysia turut menyentuh isu "minat" dalam kerjaya graduan yang mana "minat" adalah amat penting dalam satu-satu pekerjaan. Dari minat akan timbulnya kepuasan kerja dan keazaman untuk melakukan yang lebih baik. Dari analisis yang dilakukan bagi graduan SBC tahun 2008, hampir setiap kerjaya yang dilakukan oleh graduan adalah berdasarkan minat mereka iaitu sebanyak 99 peratus. Faktor pertukaran kerjaya yang berlaku dalam kalangan graduan bukan disebabkan faktor tidak minat tetapi pertukaran kerjaya berlaku adalah disebabkan faktor kenaikkan pangkat serta mendapat peluang kerjaya yang memberi kelebihan dari sudut pendapatan bulanan yang lebih tinggi dari pendapatan bagi kerjaya sebelumnya. Hanya terdapat satu pekerjaan yang tidak diminati oleh seorang graduan yang mewakili 1 peratus bagi jumlah keseluruhan kerjaya mengikut tahun. Selain itu, minat amat penting bagi graduan dalam menimba pengalaman dan mengasah kemahiran dalam proses mengenali sesuatu kerjaya yang diceburi. Dari minat juga akan timbul sikap- sikap positif dalam mencapai kejayaan dalam kerjaya. Dari analisis yang dilakukan pada graduan SBC tahun 2007 juga memperlihatkan hampir setiap kerjaya yang dilakukan oleh graduan adalah berdasarkan minat mereka iaitu sebanyak 99 peratus. Tetapi terdapat satu pekerjaan yang tidak diminati oleh seorang graduan yang mewakili 1 peratus bagi jumlah keseluruhan kerjaya mengikut tahun. Kebanyakkan graduan-graduan ini memiliki kerjaya dalam sektor pembinaan dan kebanyakkan dari mereka menjawat jawatan yang mereka minati. Walau bagaimanpun, masih kurang jelas tentang "minat" yang dimaksudkan. Justeru, adakah minat sahaja boleh mempengaruhi kejayaan dan kestabilan kerjaya seseorang? Isu ini telah mendorong pengkaji untuk menjalankan kajian lanjutan bagi mengenal pasti faktor yang mempengaruhi kerjayaan graduan Sarjana Muda Sains Pembinaan Universiti Teknologi Malaysia. 


\section{Objektif}

Mengenal pasti faktor- faktor yang mempengaruhi kejayaan dalam kerjaya graduan Sarjana Muda Sains Pembinaan.

\section{Teori Pemilihan Kerjaya}

\section{Teori Tret Dan Faktor}

Tret merupakan keupayaan yang terdapat di dalam seseorang manusia. Setiap individu mempunyai kebolehan dan keupayaan atau tret yang unik dan berbeza. Setiap dari mereka berusaha untuk mengenal pasti tret-tret mereka dan mencari jalan untuk hidup dan bekerja yang membolehkan mereka menggunakan kebolehan- kebolehan yang mereka miliki secara berkesan. Teori Tret dan Faktor diasaskan oleh Frank Parson merupakan teori yang mengandaikan bahawa setiap manusia yang wujud di dalam dunia adalah unik dan berbeza. Selain itu, teori ini menyatakan manusia mempunyai kemampuannya yang unik serta tret- tret tertentu yang boleh diukur dengan tepat, konsisten dan selaras. Selain itu, teori ini juga mempunyai perkaitan dengan keperluan- keperluan asas dalam beberapa jenis pekerjaan. Teori ini adalah satu pendekatan yang berasaskan penilaian terhadap bakat, sikap individu dan keperluannya dalam satu- satu kerjaya. Dalam memilih kerjaya yang baik, individu perlu mempunyai kefahaman yang jelas terhadap diri, pengetahuan tentang pekerjaan dan taakulan yang tetap tentang hubungan kedua- duanya. Taakulan merupakan perihal membuat pertimbangan dan penilaian melalui akal (Kamus Dewan Bahasa Edisi Keempat, 2005).

Teori ini merupakan teori yang kognitif di mana ianya membantu dalam memudahkan proses pemilihan kerjaya dilakukan apabila segala maklumat berkaitan dengan diri telah diperoleh dan digunakan. Kognitif merupakan satu istilah di mana agama dianggap sebagai cara dalam memenuhi keperluan (Kamus Dewan Bahasa Edisi Keempat, 2005). Selain itu juga, terdapat tiga komponen asas dalam bimbingan kerjaya iaitu ujian, pemberian maklumat dan taakulan terhadap keputusan secara rasional. Sebahagian besar manusia merupakan individu yang rasional serta mempunyai kebolehan dalam membuat pilihan yang terbaik asalkan mempunyai maklumat yang cukup dalam mengasakan pemilihan kerjaya. Antara tugas utama yang terlibat dalam proses pemilihan kerjaya ialah dengan memadankan individu dengan sesuatu pekerjaan. Dalam Teori Tret dan Faktor ini, setiap individu mempunyai tret yang tertentu yang terbentuk hasil daripada interaksi antara individu dan persekitaran. Setiap individu perlu mempunyai satu tret atau lebih untuk mencapai tahap kejayaan dalam kerjaya. Walau bagaimanapun, teori ini mempunyai kelemahan iaitu melibatkan kegagalan dalam menangani proses membuat pemilihan kerjaya. Ini kerana, teori ini menyangka bahawa kebolehan membuat keputusan adalah berkaiatan dengan tret-tret tertentu. Selain itu juga, teori ini menjangka bahawa terdapat proses yang digunakan bagi membuat keptusan yang sistematik yang boleh dipelajari.

\section{Teori Pemilihan Kerjaya Anne Roe}

Anne Roe telah memperkenalkan Teori Pemilihan Kerjaya Anne Roe dengan mengintegrasikan teori personaliti dengan klasifikasi pekerjaan yang bertujuan bagi melihat pengaruh latar belakang keluarga dan pengalaman layanan ibu bapa semasa kanak- kanak dengan semua bidang pekerjaan. Setiap manusia mempunyai personaliti yang berbeza yang dapat dikelompokkan. Oleh itu, setiap pekerjaan yang dipilih oleh individu adalah berkaitan dengan jenis personaliti yang dimiliki oleh individu tersebut. Dalam teori ini, terdapat beberapa faktor yang mempengaruhi pemilihan kerjaya antaranya latar belakang genetik. Latar belakang genetik dapat mempengaruhi minat, kecerdasan, sikap dan personaliti serta sifat fizikal seperti ketinggian, kecantikan dan kecacatan individu tersebut yang kemudiannya mempengaruhi pemilihan kerjaya. Pengaruh genetik dan hierarki keperluan juga mempengaruhi pemilihan kerjaya individu. Keperluan terbentuk sehingga ia mencapai tahap keperluan diri yang tertinggi iaitu kesempurnaan kendiri. Pengaruh genetik akan mempengaruhi individu dalam menentukan perbezaan bagi mencapai sesuatu kerjaya di mana pada masa yang sama keperluan yang dimiliki menjadi sumberr motivasi dalam menggerakkan diri demi memenuhi kehendak. Selain itu, faktor lain adalah pengaruh tenaga psikik. Pembentukan sifat kepuasan dan kekecewaan yang dialami 
oleh individu pada zaman kanak- kanaknya akan mempengaruhi perkembangan keupayaannya secara sedar atau tidak sedar. Keperluan dari peringkat kanak- kanak adalah paling penting dalam membentuk kerjaya individu semasa dewasa kerana pengaruh pekembangan kanak- kanak adalah berdasarkan keperluan yang diperlukan olehnya dalam membuat keputusan kerjaya.

Gaya layanan ibu bapa mempengaruhi kecenderungan individu dalam membuat pemilihan kerjaya. Hal ini diwarisi melalui tiga teknik asas layan ibu bapa semasa berinteraksi dengan anak- anak mereka iaitu gaya layanan mesra, gaya layanan dingin dan gaya layanan menumpu. Gaya layan mesra dibahagikan kepada mesra bersahaja dan mesra pengasih. Melalu mesra bersahaja, ibu bapa memberi perhatian dan kasih sayang kepada anak- anak pada tahap yang sederhana dan terdapat undang yang dikuatkuasakan dan dilaksanakan oleh ibu bapa tetapi dilakukan sambil lewa. Manakala bagi mesra pengasih, ibu bapa cenderung dalam membantu anak- anak mereka dalam menyelesaikan masalah yang sukar dan penting serta mereka memberi pujian dan kebebasan yang munasabah kepada anakanak mereka dan pada masa yang sama mereka mencurahkan kasih sayang dan kemesraan kepada anak- anak. Gaya layan dingin lebih kepada sifat tidak ambil peduli. Gaya ini juga terbahagi kepada dua iaitu dingin mengabai dan dingin mengelak. Dalam dingin mengabai, ibu bapa sukar untuk menepati janji dan kurang member layan fizikal. Manakala bagi dingin mengelak, ibu bapa lebih suka merendah- rendahkan dan menghina anak- anak mereka serta tidak ambil berat dan sentiasa bersifat dingin. Selain itu terdapat gaya layan menumpu yang terbahagi kepada dua iaitu terlampau melindungi dan terlampau menuntu. Ibu bapa yang mengamalkan gaya terlampau melindungi, mereka member perhatian kepada minat, memanjakan, memberi kasih sayang, menjaga keselamatan dan kurang memberi kebebasan kepada anak- anak mereka. Manakala ibu bapa yang terlampau menuntu mahukan anak- anak mereka melibatkan diri dalam aktiviti yang berguna dari sudut pandangan mereka. Ibu bapa cenderung untuk mendenda atau menghalang hubungan anak-anak dengan rakan sebaya dengan penggunaan peraturan- peraturan yang keras, tegas dan anak- anak tidak boleh membantah.

Dari sudut orientasi teori ini, orientasi pekerjaan merujuk kepada bidang- bidang pekerjaan yang terbahagi kepada dua iaitu berorientasikan manusia dan tidak berorientasikan manusia. Pekerja yang bekerja dalam bidang pekerjaan yang berorientasikan manusia selalunya datang dari keluarga yang mesra dan penuh kasih sayang serta diterima oleh ibu bapa. Bagi pekerja yang bekerja dalam bidan pekerjaan yang tidak berorientasikan manusia pula datang dari keluarga yang mengalami suasana hidup yang dingin dan tidak mempedulikan keperluan emosinya. Teori Pemilihan Kerjaya Anne Roe ini memperlihatkan hubungan antara persekitaran tertentu pada peringkat kanak- kanak, perkembangan keperluan kanak- kanak, personaliti serta pemilihan kerjaya. Setiap individu yang dilahirkan mempunyai tret- tret psikologikal tertentu serta mempunyai kekuatan dan kelemahan fizikal. Selain itu kepentingan demografi sosial dalam kalangan individu juga memainkan peranan penting dalam pemilihan kerjaya. Tetapi kelemahan teori ini adalah kegagalan dalam mengambil kira proses keputusan pemilihan sesuatu kerjaya tersebut dilakukan sebenarnya.

\section{Teori Psikoanalitik Bordin}

Teori Psikoanalitik Bordin merupakan sebuah teori perkembangan hidup yang memberi penekanan terhadap kerjaya. Psikoanalitik bermaksud tingkah laku manusia yang dipengaruhi oleh proses- proses psikologi tidak sedar seperti konflik dalaman. Teori ini menyatakan keperluan biologi atau dorongan dan atmosfera keluarga yang berinteraksi dapat menghasilkan jenis personality pembentukan awal yang member pengaruh perkembangan personalti anak- anak yang juga berdasarkan identifikasi kedua ibu bapa. Apabila persamaan yang tinggi wujud antara anak- anak dan ibu bapa di mana permintaan luaran adalh seiring dan selari dengan kehendak untuk mendapatkan kepuasan, maka kerja yang dilakukan akan menjadi satu pengalaman yang amat menggembirakan. Teori ini juga sangat menekankan keupayaan dalam mengubah tindakan kepada satu perlakuan yang dapat diterima masyarakat. Pemilihan kerjaya mengikut teori ini banyak mempengaruhi pemikiran di bawah sedar dan mekanisme dalam membela diri.

Perkara tersebut adalah berdasarkan dimensi agresif secara oral dan dimensi manipulatif. Dalam dimensi agresif secara oral, kepuasan adalah mengenai perkembangan personaliti pada peringkat oral yang dikaitkan dengan aktiviti- aktiviti harian. Manakala kepuasan dari sudut kerjaya merupakan 
kepuasan yang diperolehi dengtan melibatkan diri dalam sesuatu aktiviti yang berkaitan dengan kerjaya. Menurut dimensi manipulatif pula, manipulatif fizikal adalah penggunaan kaedah atau cara psikologi untuk mempengaruhi atau mengawal orang lain. Dalam teori ini, masalah pemilihan kerjaya akan timbul apabila kerja yang dilaksanakan tidak memenuhi keingin dan kepuasan kepada individu. Model teori ini tidak menyampaikan secara jelas inti pati yang terkandung di dalam teori yang menjadikan teori ini lemah dalam mendefinikan maksud. Teori ini juga bukan teori heuristik tetapi teori ini berguna serta dapat memberikan sumbangan dalam kaunseling kerjaya untuk memahami beberapa faktor dalam berlakunya dilemma pemilihan kerjaya. Heuristik merupakan satu langkah yang membolehkan atau dapat membantu individu untuk mempelajari, mengetahui dan sebagainya tentang sesuatu perkara melalui pengalaman sendiri.

\section{Teori Pemilihan Kerjaya Holland}

Teori Pemilihan Kerjaya Holland merupakan hasil kajian Holland terhadap personaliti yang dipengaruhi oleh Teori Tret dan Faktor. Teori ini menjelaskan tentang pembentukan dan perkembangan personaliti dan menyatakan asas dalam menekankan aspek keselarasan antara jenis personality dengan persekitaran. Secara amnya, asas teori ini terbentuk dari andaian tentang minat vokasional individu yang juga merupakan salah satu aspek personaliti yang menerangkan bahawa minat individu juga mempengaruhi personalitinya. Selain itu, teori ini juga memfokuskan mengenai tingkah laku vokasional serta mencadangkan idea yang praktikal bagi membantu individu untuk membuat pemilihan kerjaya, menukat kerjaya dan memperoleh kepuasan dalam kerjaya. Dalam andaian asas teori ini, Holland menerangkan setiap jenis personaliti terbentuk dari hasil interaksi pelbagai desakan budaya dan personalyang mempunyai kaitan dengan budaya Amerika. Kebanyakkan individu tergolong dalam beberapa jenis kumpulan personaliti iaitu Realistik (R), Investigatif (I), Artistik (A), Sosial (S), Enterprising (E) dan Conventional (C). Hasil dari interaksi individu dengan faktor yang disenaraikan menjadikan individu menyukai aktiviti- aktiviti yang berkaitan dengan faktor tersebut sehingga mampu membentu satu kumpulan yang mempunyai kecekapan yang sama. Hasilnya mereka berpotensi untuk berfikir dan membuat tanggapan dan tingkah laku yang tertentu.

Selain itu, terdapat enam jenis persekitaran iaitu Realistik (R), Investigatif (I), Artistik (A), Sosial (S), Entreprising (E) dan Conventional (C). Bagi Holland, setiap persekitaran ini akan dikuasai oleh setiap jenis personaliti tertentu yang dijeniskan dalam bentuk fizikal yang dapat menghasilkan masalahmasalah serta peluang- peluang tertentu. Kemudian, individu akan mencari persekitaran- persekitaran yang akan memberikan mereka peluang dalam mengamalkan kemahiran serta kemampuannya, dapat melahirkan sikap dan nilai- nilainya serta mengambil segala permasalahan dan peranan yang dipersetujui yang wujud dalam persekitaran tersebut. Dalam andaian sekunder teori ini, Holland menyatakan setiap individu akan menunjukkan tingkah laku dan cirri- cirri yang berkaitan dengan personaliti tersebut setelah individu tersebut hampir menyerupai sesuatu jenis personaliti. Model heksagonal yang dicipta oleh Holland dapat digunakan dalam mentakrif darjah keselarasan antara jenis personalti dengan persekitaran. Konsep keselarasan akan berlaku apabila inividu bekerja atau tinggal dalam persekitaran yang sama dengan jenis personalitinya. Manakala ketidakselarasan pula terjadi apabila individu tersebut tinggal atau bekerja dalam persekitaran yang tidak sama dengan perosnalitinya. Tahap keselarasan antara jenis personaliti dengan jenis persekitaran di jelaskan dalam Jadual 1 berdasarkan Rajah 1.

Jadual 1: Tahap Keselarasan Antara Jenis Personaliti Dengan Jenis Persekitaran

\begin{tabular}{llll}
\hline Paling Selaras & Kedua Selaras & Ketiga Selaras & Paling Tidak Selaras \\
\hline R-R, I-I, A-A, S-S, & R-I, R-C, I-A, I-R, & R-E, R-A, I-C, & R-S, S-R, I-E, \\
E-E, C-C & A-S, A-I, S-E, S-A, & I-S, A-R, A-E, & E-I, A-C, C-A \\
& E-C, E-S, C-R, & S-I, S-C, E-A, & \\
& C-E & E-R, C-S, C-I & \\
\hline
\end{tabular}




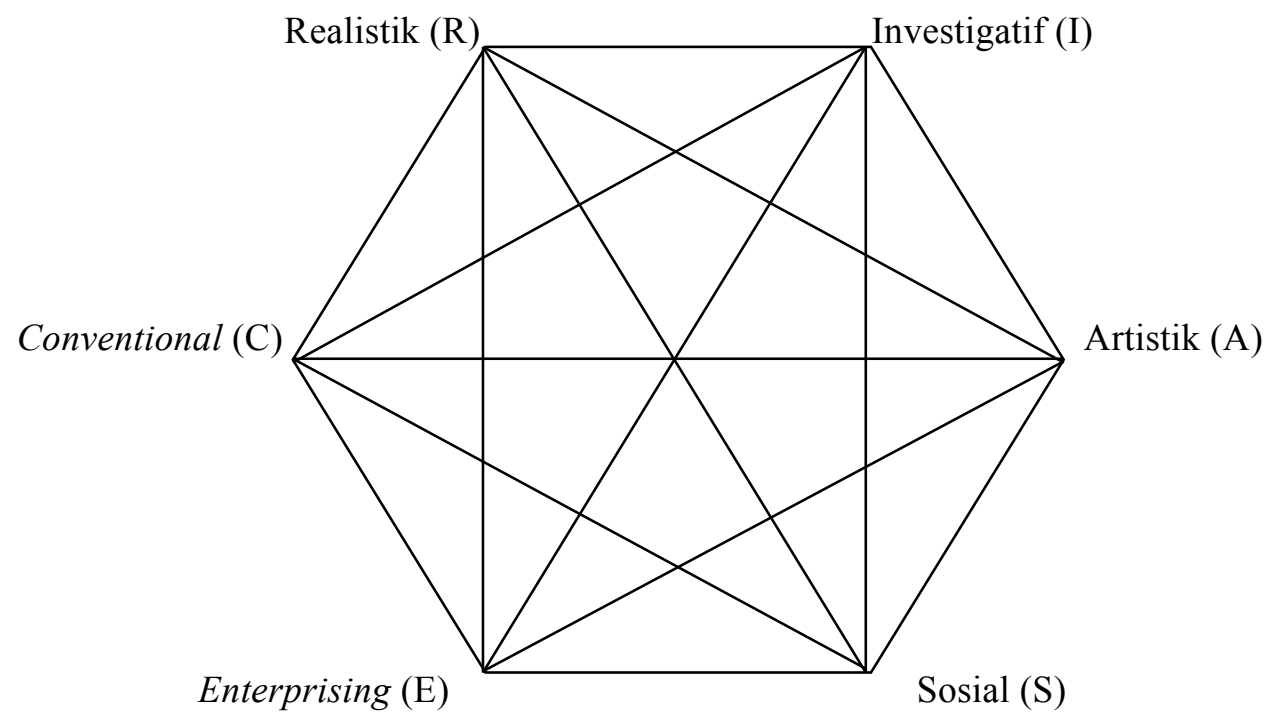

Rajah 1: Model Heksagonal Holland

Konsep konsistensi atau ketekalan corak personaliti ditentukan oleh darjah kesamaan antara jenis personaliti yang mempunyai ciri- ciri yang sama dengan yang ditunjukkan dalam model heksagonal. Teori ini menjelaskan bahawa hubungan sesetengah personaliti dan persekitaran adalh lebih kuat dari pasangan personaliti dan persekitaran yang lain. Jadual 2 menunjukkan tahap konsistensi dan pola personaliti yang berkaiatn dengan tahap- tahap itu.

\section{Jadual 2: Tahap Ketekalan Dan Pola Personaliti}

\begin{tabular}{ll}
\hline Tahap Ketekalan & Pola Personaliti \\
\hline Tinggi & RI, RC, IR, IA, AI, AS, SA, SE, ES, EC, CE dan CR \\
Sederhana & RA, RE, IS, IC, AR, AE, SI, SC, ER, CS dan CI \\
Rendah & RS, IE, AC, SR, EI dan CA \\
\hline
\end{tabular}

Dari konsep pembezaan, individu atau persekitaran yang menunjukkan kesamaan terhadap keenamenam jenis dianggap sebagai individu yang tidak mempunyai pembezaan. Manakala sesetengah individu tersebut menunjukkan keserupaan yang tinggi kepada satu jenis dan kurang keserupaan pada jenis lain. Dalam konsep kalkulus, pertalian antara jenis personaliti dan persekitaran dapat dikenal pasti melalui model heksagonal dengan jarak antara jenis personaliti dan persekitaran. Ini bermakna semakin jauh jarak antara jenis personaliti atau persekitaran, semakin berbeza ciri- ciri psikologikalnya. Manakala konsep yang terakhir iaitu konsep identiti menerangkan tentang anggaran identiti personal atau identiti persekitaran secara jelas dan stabil. Identiti personal bermaksud terdapatnya gambaran yang jelas dan stabil tentang matlamat, nilai dan bakat individu. Manakala identiti persekitaran bermaksud terdapatnya pemerhatian terhadap organisasi atau persekitaran di mana menyatakan matlamat yang jelas, tugas serta ganjaran yang jelas dan bersepadu yang stabil dalam satu jangka masa yang panjang. Teori Pemilihan Kerjaya Holland merupakan teori yang terbaik dan mantap kerana berjaya mengemukakan andaian, saranan serta gagasan yang jelas serta mudah difahami yang berkaitan dengan pemilihan kerjaya individu. Ini kerana beliau berjaya mengaitkan keadaan personaliti seseorang yang dipengaruhi oleh keadaan persekitaran melalui beberapa konsep yang disenaraikan dan secara jelas melalui model heksagonal ciptaannya dengan menerangkan hubungan jenis personaliti dengan persekitaran yang berjaya diintegrasikan dengan baik. Selain menerangkan tentang pemilihan kerjaya, teori ini juga sesuai untuk menerangkan tentang kepuasan dan pertukaran kerja. 
DOI: https://doi.org/10.47405/mjssh.v5i6.422

\section{Persediaan dalam Mencari dan Mendapatkan Perkerjaan}

\section{Faktor Yang Mempengaruhi Kerjaya}

Faktor ini dikatakan memberi sumbangan terhadap perkembangan kerjaya yang perlu diberi perhatian sebelum membuat mana- mana pemilihan kerjaya:

Faktor Genetik: Faktor genetik akan menentukan darjah kecerdasan, paras rupa, warna kulit, jantina, kecacatan pada anggota dan bentuk fizikal badan seperti ketinggian dan berat badan.

Faktor Pendidikan dan Pembelajaran: Pendidikan dan pembelajaran berlaku dalam keadaan formal dan tidak formal. Dalam pendidikan dan pembelajaran yang ditempuhi, individu akan dapat membina personaliti, minat, nilai, konsep kendiri, sikap, kebolehan, pencapaian dan pandangan umum tentang kehidupan. Aspek psikologi seseorang individu itu banyak terbentuk melalui proses pendidikan dan pembelajaran.

Faktor Persekitaran: Dalam aspek persekitaran, tempat individu tinggal juga menjadi faktor kepada pemilihan dan perkembangan kerjaya. Umumnya pekerjaan individu banyak berkaitan dengan persekitaran dalam kawasannya seperti soal politik, ekonomi dan sosial. Penentuan terhadap soal politik selalunya dikaitkan dengan kestabilan politik dan keamanan negara serta perhubungan antarabangsa dengan negara lain. Penentu terhadap sola ekonomi pula melibatkan perubahan teknologi, aliran perdagangan, peperangan serta jenis- jenis perniagaan. Terakhir adalah melibatkan penentuan sosial di mana ia meliputi tahap pelajaran, sosioekonomi, kewarganegaraan dan bangsa.

Faktor Agama: Faktor- faktor yang mempengaruhi pemilihan kerjaya adalah berasakan teori Barat. Namun begitu dalam Islam penentu akhir terhadap perkembangan dan pemilihan kerjaya individu adalah sama ada kerjaya itu haram atau halal. Di dalam Islam tiada kompromi. Kompromi mungkin wujud untuk kerjaya- kerjaya yang mempunyai unsure- unsure syubhah atau syak wasangka atau kerjaya yang terletak di antara halal dan haram. Perbezaan yang sangat jelas anta teori Islam dan teori Barat adalah teori kerjaya Barat lebih menekankan aspek kepuasan dan kejayaan duniawi manakala dalam Islam member penekanan terhadap keseimbangan antara kejayaan dan kepuasan duniawi dan akhirat.

\section{Faktor Yang Membantu Untuk Mencari Kerja}

Minat: Minat terhadap sesuatu pekerjaan mendorong kepada pelajar untuk membuat pengkhususan kepada kursus- kursus yang diminati pada peringkat pengajian tinggi dan seterusnya melangkah ke pekerjaan ke pekerjaan yang diidamkan. Memohon sesuatu pekerjaan atau tugas yang di luar batas minat individu akan menyebabkan keputusan berhenti kerja akan timbul ekoran permasalahan yang dihadapi dalam badang yang tidak diminati.

Kelayakkan Akademik/ Kemahiran: Kelayakan akademik yang dimaksudkan adalah SPM, STPM, sijil kemahiran, diploma, ijazah dan juga kelulusan professional. Kelayakan ini digunakan mengikut keperluan majikan dalam pekerjaan yang dipohon. Dalam era permidenan yang semakin pesat membangun kebanyakkan pekerjaan memerlukan kelulusan ijazah sarjana muda dan pendapatan pula bergantung terhadap kelayakan akademik ata kemahiran pemohon. Terdapat sesetengah pekerjaan memerlukan kelulusan khusus seperti jururawat, doctor, jurutera dan lain dan sesetengah pekerjaan pula hanya memerlukan sijil atau diploma kemahiran teknikal.

Pengalaman Kerja/Latihan Industri: Setiap individu atau pelajar yang mempunyai pengalaman kerja atau pernah menjalani latihan industri/ praktikal akan mendapat kelebihan dalam memohon pekerjaan. Ini kerana pengalaman juga memainkan peranan yang penting dalam permohonan kerjaya yang ditawarkan. Bagi majikan khususnya sektor swasta, mereka melihat kepada pengalaman pekerjaan yang ada berkaitan dengan bidang yang dipohon sebelum penawaran diberikan. Bagi mereka yang mempunyai pengalaman dalam latihan industri atau praktikal selain pengalaman pekerjaan, hal ini juga membantu dalam permohonan mencari kerja. 
Kemahiran Teknologi Komunikasi dan Maklumat (ICT): Mahir di dalam bidang ICT adalah satu kelebihan yang dicari oleh majikan. Di zaman siber ini setiap penggunaan teknologi maklumat termasuk komputer begitu meluas sama ada dalam sektor awam mahupun swata. Ini kerena majikan memerlukan individu atau graduan yang mempunyai kemahiran teknologi maklumat dan computer bagi memenuhi keperluan syarikat organisasi dan pasaran.

Kemahiran Berkomunikasi: Dalam mencari pekerjaan, kemahiran komunikasi ini juga penting dalam berinteraksi pada setiap masa sama ada secara lisan atau bukan lisan. Tanpa adanya kemahiran berkomunikasi akan menyebabkan kesulitan dalam melakukan kerja. Kemahiran komunikasi akan dilihat dan dinilai sewaktu individu ditemu duga dan kejayaan dalam proses temu duga tersebut bergantung kepada kemahiran ini.

Penguasaan Bahasa Inggeris: Penguasaan bahasa Inggeris dapat memberi satu kelebihan pada bakal pekerja. Dalam sektor swasta, penggunaan bahasa Inggeris adalah meluas dalam urusan seharian mereka. Semasa menghadiri temu duga kerja di sektor swasta biasanya menggunakan bahasa Inggeris dalam sesi tersebut. Ini kerana sektor swasta lebih menggunakan bahasa Inggeris berbanding bahasa Melayu dalam urusan perniagaan atau perkhidmatan mereka (Mohd Yahya \& Muhammad Haizuan, 2001). Sekiranya individu tersebut tidak dapat menguasai bahasa Inggeris dengan baik, masalah akan timbul untuk mendapatkan kerja dan membuatkan individu tersebut mula tiada keyakinan diri dan bimbang untuk memohon kerja di sektor swasta.

Penguasaan Bahasa Melayu: Bakal pekerja khususnya dalam sektor awam harus menguasai bahasa Melayu oleh kerana penggunaan bahasa Melayu adalah meluas dalam perkhidmatan awam. Semua jawatan dalam sektor awam mwajibkan setiap individu yang memohon mendapat kepujian dalam bahasa Melayu di peringkat Sijil Pelajaran Malaysia (SPM) atau setaraf. Mereka yang bekerja dalam sektor swasta juga perlu menguasai bahasa Melayu kerana terdapat urusan dengan jabatan- jabatan kerajaan selain perlu berurusan dengan pengguna dan orang ramai.

\section{Ciri- ciri Yang Diperlukan Oleh Majikan}

Kelulusan akademik yang baik adalah tidak menjamin peluang pekerjaan yang baik. Malah kejayaan yang berasaskan akademik semata- mata juga tidak dapat menentukan individu tersebut berjaya dalam bidang yang diceburi atau dapat berinteraksi dengan rakan sekerja dengan baik. Setiap majikan mempunyai kriteria yang tertentu dalam memilihan bakal pekerjanya. Oleh itu, bersedia untuk menanamkan ciri- ciri yang positif dalam diri setelah menerima tawaran kerja.

Berdikari: Apabila tugas dijalankan dengan berdikari, di tambah pula dengan prestasi yang baik sudah tentu akan mendapat perhatian majikan. Jangan terlalu bergantung kepada orang lain dan sikap ini amat dipuji. Majikan mahukan seorang pekerja yang matang, bijak, bertanggungjawab dan tekun.

Berinisiatif: Semasa menjalankan tugas, usaha dan bekerja keras amat diperlukan. Jangan terlalu bergantung kepada orang lain kerana setiap orang mempunyai tugas masing- masing. Pada peringkat permulaan pekerjaan, adalah digalakkan untuk bertanya dan mempelajari sesuatu dari kakitangan yang berpengalaman. Tetapi pada yang sama inisiatif sendiri diperlukan dalam memastikan segala kerja berjalan dengan lancar. Jangan sekali- kali mengambil mudah atas kerja yang diberikan. Pastikan segala tugasan yang diberikan disiapkan pada tarikh dan masa yang ditetapkan oleh ketua kerana suka menangguhkan kerja- kerja yang diberikan akan menyebabkan tekanan kerana kerja semakin bertambah. Lakukanlah kerja sebaik mungkin dalam proses untuk "memasarkan diri" kepada majikan. Sebagai pekerja yang baru, perancangan awal perlu dilakukan untuk mencapai kejayaan melalui perancangan matalamat diri dan organisasi serta mencari cara untuk mencapai kejayaan kelak.

Kemahiran Berkomunikasi: Kemahiran berkomunikasi amat penting kepada setiap pekerja. Secara rasmi atau tidak rasmi, berkomunikasi itu adalah penting untuk berkomunikasi dengan masyarakat atau rakan sekerja. Keupayaan berkomunikasi dengan baik dan berkesan serta mempunyai kekuatan dalam penguasaan bahasa akan dapat menampilkan profesionalisme individu tersebut. Jika dapat 
memberi idea dan pendapat, majikan dan rakan sekerja akan yakin dengan keupayaannya. Dapat berkomunikasi dengan baik akan mememudahkan penyesuaian diri dengan pelbagai [ihak temasuk pengurusan atasan, klien, rakan sepejabat dan orang awam.

Sesuaikan Dengan Budaya Dan Persekitaran: Persekitaran kerja meliputi rakan- rakan sekerja, kakiktangan di bahagian lain serta persekitaran fizikal termasuk ruang pejabat dan bangunan. Penyesuaian diri dengan tempat kerja adalah perlu dengan memahami dan mempelajari persekitaran tempat kerja. Masalah tidak dapat menyesuaikan diri dengan tempat kerja dan rakan sepejabat boleh dianggap serius kerana terdapat pekerja baru yang terpaksa meletakkan jawatan walaupun masih dalam tempoh percubaan.

Berdisiplin: Dalam dunia pekerjaan, sebagai pekerja baru, individu yang terpilih harus menjaga tingkah laku, berdisiplin, mengikut peraturan kerja, menampakkan komitmen dan komited untuk bekerja. Perkara- perkara ini amat penting dalam perkembangan kerjaya dalam organisasi tempat kerja. Malah faktor ini juga diambil kira oleh majikan dalam menilai prestasi untuk kenaikkan pangkat dan gaji.

Berpakaian Secara Profesional: Pemakaian yang sesuai dengan pekerjaan adalah mustahak supaya dapat kelihatan segak, kemas, anggun dan menarik. Cara berpakaian sewaktu di pejabat atau sewaktu bekerja menjadi nilai utama sebelum seseorang mengenali pekerja baru terutama rakan sekerja. Pada umumnya, setiap individu perlu bijak dalam menyesuaikan kombinasi warna dengan pakaian agar dapat kelihatan seperti professional dan elakkan dalam memilih warna yang garang yang boleh menyebabkan orang lain tidak selesa.

Kesihatan Yang Baik: Badan yang sihat dapat menyediakan otak yang cerdas. Setiap pekerja harus mempunyai kesihatan diri yang baik. Apabila mendapat tawaran kerja, setiap majikan akan meminta untuk melakukan pemeriksaan doctor sebelum melaporkan diri. Majikan akan menggunakan laporan tersebut untuk menganalisa pekerja baru bagi mengetahui status kesihatan pekerjanya. Jika sering kali jatuh sakit, hal ini akan menyebabkan pekerja baru gagal dalam melaksanakan tugasnya disebabkan gagal memberi tumpuan dalam pekerjaan dan menyebabkan produktiviti kerja menurun. Usaha yang bersungguh- sungguh perlu dalam memastikan kejayaan dalam kerjaya dapat dicapai. Berazam untuk menyandang jawatan tinggi, untuk memperoleh gaji yang lumayan, maka berusahalah untuk mencapainya. Pembentukkan diri adalah penting untuk menyenangkan majikan, rakan dan teman sepejabat untuk bersama- sama melakukan perubahan.

\section{Faktor Kejayaan Satu Bidang Kerjaya}

Terdapat beberapa faktor yang menjadi kunci kejayaan dalam sesuatu kerjaya antaranya, yang pertama ialah rasa minat dan bertanggungjawab individu tersebut kepada kerjayanya di samping menyediakan imej kendiri yang sesuai bagi satu- satu kerjaya. Kedua, Tiada diskriminasi atau kezaliman yang terjadi iaitu sifat membeza- bezakan antara satu puak atau kaum dengan puak atau kaum yang lain seperti penindasan dan tidak berlaku adil. Selain itu, mendapat gaji yang setimpal dengan pekerjaan yang dilakukan kerana gaji merupakan hak individu yang bekerja setelah melakukan sesuatu perkhidmatan, Permusuhan antara pekerja dan majikan tidak dibenarkan dalam Islam demi menjaga etika kerja. Orang atasan atau pihak pengurusan perlu bersikap lemah lembut dan mempunyai kasih saying kepada orang bawahanmanakal pekerja bawahan perlu menghormati pihak atasan. Pekerja wajib mematuhi segala perintah dari pihak atasan selagi tidak bertentangan dengan Islam. Fokusnya dalah saling tolong- menolong (mu'awanah), saling membahagiakan (musa'ada) serta saling menyokong (mu'dhadah). Dan yang terakhir dengan mewujudkan hubungan dalam masyarakat seperti bergaul mesra antara rakan sekerja, besikap baik dan jujur sewaktu bekerja.

\section{Metod Kajian}

Kajian ini dijalankan dengan menggunakan kaedah kuantitatif yang terhasil dari pembacaan sumber ilmiah seperti e-jurnal, artikel, dokumen, duku dan persidangan sebelum ini yang telah dinilai dan 
dimuat turun dari enjin carian internet. Beberapa data sekunder berkaitan juga diperolehi daripada perpustakaan universiti, Perpustakaan Sultanah Zanariah dan Perpusatakaan Raja Zarith Sofiah, Universiti Teknologi Malaysia dan enjin carian perpustakaan. Dalam kajian ini, populasi yang terlibat ialah graduan Sarjana Muda Sains Pembinaan Universiti Teknologi Malaysia dari tahun 2007 sehingga 2008. Sejumlah 30 orang graduan terlibat dalam kajian ini. Penyelidik telah memilih penggunaan borang soal selidik dalam mendapatkan maklumat kajian.

\section{Analisis Kajian}

Penyelidik membincangkan mengenai hasil kajian yang diperolehi daripada analisis data yang diberikan oleh responden yang telah dikumpulkan melalui penggunaan borang soal selidik. Data yang diperolehi dianalisis bagi mencapai kedua- dua objektif kajian yang dijalankan pada awal kajian. Kajian analisis telah dibahagikan kepada dua bahagian iaitu bahagian pertama bagi hasil analisis graduan Sarjana Muda Sains Pembinaan bagi tahun 2008 dan bahagian kedua adalah hasil analisis graduan Sarjana Muda Sains Pembinaan bagi tahun 2007.

\section{Profil Responden - Graduan Sarjana Muda Sains Pembinaan (SBC) 2008}

Bagi analisis graduan tahun 2008, sejumlah 15 borang soal selidik diterima dan telah dianalisis. Kesemua responden ini merupakan Graduan Ijazah Sarjana Muda Sains Pembinaan yang menerima penganugerahan masing- masing pada tahun 2008. Analisis terhadap pengalaman bekerja responden menunjukkan sebanyak 2 orang responden (13\%) telah bekerja kurang dari 4 tahun. Seramai 12 orang responden $(80 \%)$ telah kerja antara 4 tahun sehingga 6 tahun. Manakala baki 7 peratus responden telah bekerja lebih dari 6 tahun. Menurut analisis, graduan yang bekerja kurang 4 tahun adalah disebabkan mereka melanjutkan pelajaran ke peringkat Master.Manakala, responden yang bekerja lebih dari 6 tahun adalah kerana responden tersebut bekerja selepas menamatkan diploma sebelum meneruskan ke peringkat Sarjana Muda Sains Pembinaan. Pekerjaan yang dijawat olehnya adalah sebagai Pentadbir Kontrak dan telah menamatkan pekerjaan tersebut untuk menyambung pelajaran ke peringkat sarjana muda di UTM. Jadual 3, menunjukkan jantina dan status responden. Secara keseluruhan, terdapat 60 peratus responden lelaki yang mewakili 9 orang dan 40 peratus responden perempuan yang mewakili 6 orang. Bagi analisis status perkahwinan, 47 peratus responden adalah bujang yang mewakili 7 orang manakala 53 peratus responden lagi telah berkahwin yang mewakili seramai 8 orang.

Jadual 3: Maklumat Diri Responden Berdasarkan Pengalaman Bekerja

\begin{tabular}{|c|c|c|c|c|c|c|c|c|c|c|}
\hline \multirow[t]{3}{*}{ Pengalaman Bekerja } & \multirow{2}{*}{\multicolumn{2}{|c|}{$\begin{array}{l}\text { Jumlah } \\
\text { Responden }\end{array}$}} & \multicolumn{4}{|c|}{ Jantina } & \multicolumn{4}{|c|}{ Status } \\
\hline & & & \multicolumn{2}{|c|}{ Lelaki } & \multicolumn{2}{|c|}{ Perempuan } & \multicolumn{2}{|c|}{ Bujang } & \multicolumn{2}{|c|}{ Berkahwin } \\
\hline & Bil. & $\%$ & Bil. & $\%$ & Bil. & $\%$ & Bil. & $\%$ & Bil. & $\%$ \\
\hline Kurang Dari 4 Tahun & 2 & $13 \%$ & 0 & $0 \%$ & 2 & $13 \%$ & 0 & $0 \%$ & 2 & $13 \%$ \\
\hline 4 Tahun Sehingga 6 Tahun & 12 & $80 \%$ & 9 & $60 \%$ & 3 & $20 \%$ & 7 & $47 \%$ & 5 & $33 \%$ \\
\hline Lebih Dari 6 Tahun & 1 & $7 \%$ & 0 & $0 \%$ & 1 & $7 \%$ & 0 & $0 \%$ & 1 & $7 \%$ \\
\hline Jumlah & 15 & $100 \%$ & 9 & $60 \%$ & 6 & $40 \%$ & 7 & $47 \%$ & 8 & $53 \%$ \\
\hline
\end{tabular}

Dalam Jadual 4 dibawah merupakan pembahagian responden mengikut bangsa. Sebanyak 67 peratus responden merupakan berbangsa Melayu, 26 peratus responden adalah berbangsa Cina manakala baki 7 peratus responden merupakan bangsa India.

Jadual 4: Pembahagian Responden Mengikut Bangsa

\begin{tabular}{|c|c|c|c|c|c|c|c|c|}
\hline \multirow[t]{3}{*}{ Pengalaman Bekerja } & \multirow{2}{*}{\multicolumn{2}{|c|}{$\begin{array}{l}\text { Jumlah } \\
\text { Responden }\end{array}$}} & \multicolumn{6}{|c|}{ Bangsa } \\
\hline & & & \multicolumn{2}{|c|}{ Melayu } & \multicolumn{2}{|c|}{ Cina } & \multicolumn{2}{|c|}{ India } \\
\hline & Bil. & $\%$ & Bil. & $\%$ & Bil. & $\%$ & Bil. & $\%$ \\
\hline Kurang Dari 4 Tahun & 2 & $13 \%$ & 2 & $13 \%$ & 0 & $0 \%$ & 0 & $0 \%$ \\
\hline 4 Tahun Sehingga 6 Tahun & 12 & $80 \%$ & 7 & $47 \%$ & 4 & $26 \%$ & 1 & $7 \%$ \\
\hline Lebih Dari 6 Tahun & 1 & $7 \%$ & 1 & $7 \%$ & 0 & $0 \%$ & 0 & $0 \%$ \\
\hline
\end{tabular}


DOI: https://doi.org/10.47405/mjssh.v5i6.422

\begin{tabular}{lllllllll}
\hline Jumlah & $\mathbf{1 5}$ & $\mathbf{1 0 0} \%$ & 10 & $67 \%$ & 4 & $26 \%$ & 1 & $7 \%$ \\
\hline
\end{tabular}

\section{Analisis Laluan Kerjaya Graduan SBC 2008}

Analisis yang dijalankan mendapati, 14 daripada 15 orang responden masih bekerja sehingga 2013 manakala seorang telah menyambung pelajaran ke peringkat Ph.D di Universiti Teknologi Malaysia (UTM) pada 2013 dan beliau merupakan seorang pekerja pada tahun-tahun sebelumnya. Daripada jumlah tersebut seramai 12 orang responden memohon pekerjaan dengan menggunakan kelulusan Sarjana Muda Sains Pembinaan, 2 orang responden menggunakan kelulusan Sarjana (Master) dan seorang bagi kelulusan Diploma yang diambil sebelum melanjutkan pelajaran di peringkat Ijazah Sarjana Muda Sains Pembinaan di UTM.

\section{Analisis Terhadap Faktor-faktor Mempengaruhi Pemilihan Kerjaya Graduan SBC 2008}

Analisis yang dilakukan ini adalah berdasarkan maklum balas yang diterima dari responden menggunakan borang soal selidik yang telah diberikan kepada mereka. Berdasarkan kajian literatur, penyelidik telah menyenaraikan faktor yang mempengaruhi pemilihan kerjaya berdasarkan pembacaan terhadap teori pemilihan kerjaya terpilih. Faktor- faktor yang disenaraikan telah dikelaskan berdasarkan teori. Faktor berdasarkan keupayaan diri adalah bagi Teori Tret dan Faktor. Faktor berdasarkan pengaruh persekitaran adalah bagi Teori Pemilihan Kerjaya Holland. Faktor berdasarkan pengaruh keluarga adalah bagi Teori Pemilihan Kerjaya Anne Roe dan faktor yang terakhir berdasarkan minat dan kehendak dalaman adalah bagi Teori Psikoanalitik Bordin. Berikut merupakan hasil dari pengiraan purata perbezaan skor dan pengelasan skor menikut skala bagi mengkategorikan faktor- faktor pemilihan kerjaya yang telah dilakukan oleh graduan.

Jadual 5: Faktor- faktor yang Mempengaruhi Pemilihan Kerjaya Graduan 2008 Mengikut Kategori Mempengaruhi

\begin{tabular}{lll}
\hline Jenis Kategori & Senarai Faktor & Purata Skor \\
\hline Paling & Kerjaya yang stabil serta menjamin masa depan & 4.467 \\
Mempengaruhi & Struktur organisasi yang teratur & 4.467 \\
& Faedah kewangan seperti kadar bonus dan elaun & 4.467 \\
& Mempunyai minat terhadap kerjaya & 4.400 \\
& Mempunyai kemahiran komunikasi yang baik penting & 4.333 \\
& dalam kerjaya tersebut & \\
& Pendapatan yang berpatutan untuk membantu keluarga & 4.267 \\
& Tempat kerja yang mengamalkan nilai etika yang tinggi & 4.200 \\
& Kerja yang mudah mencapai kepuasan dalam pekerjaan & 4.133 \\
Mempengaruhi & Mempunyai kemahiran tertentu dalam kerjaya tersebut & 4.133 \\
& Berkelulusan akademik seperti yang dinyatakan dalam & 3.867 \\
& iklan & 3.867 \\
& Mempunyai kemahiran dalam ICT & 3.800 \\
& Berpengalaman dalam bidang yang sama & 3.667 \\
& Kemudahan yang disediakan seperti rumah dan kenderaa & \\
& Kemudahan di tempat kerja seperti komputer, mesin faks & 3.600 \\
& dan internet & 3.533 \\
& Waktu kerja yang fleksibel & 3.467 \\
& Lokasi tempat kerja & 3.467 \\
Tidak Pasti & Perbelanjaan dan perjalanan ke tempat kerja & 3.333 \\
& Keadaan tempat kerja yang bersih dan selesa & 3.133 \\
Tidak Mempengaruh & Kudah mendapat kenaikkan pangkat & 2.933 \\
\hline & Kerjaya yang tidak rumit dan mudah diselesaikan & 2.733 \\
\hline
\end{tabular}


DOI: https://doi.org/10.47405/mjssh.v5i6.422

\begin{tabular}{lll}
\hline & Kerjaya yang menjadi tradisi keluarga & 2.533 \\
& Mencari sesuatu kelainan dalam kerjaya antara keluarga & 2.467 \\
Paling & Keluarga yang mempunyai selok belok dalam kerjaya & 2.200 \\
Tidak Mempengaruh & $\begin{array}{l}\text { tersebut } \\
\text { Kehendak ibu bapa }\end{array}$ & 1.867 \\
\hline
\end{tabular}

Hasil daripada analisis yang telah dilakukan, penyelidik dapat mengkelaskan graduan Sarjana Muda Sains Pembinaan 2008 mengikut teori- teori pemilihan kerjaya. Hal ini adalah bertujuan bagi melihat jumlah graduan yang menggunakan teori- teori pemilihan kerjaya tertentu secara sedar mahupun tidak sedar. Rajah 2 menunjukkan jumlah graduan mengikut teori pemilihan kerjaya yang digunakan.

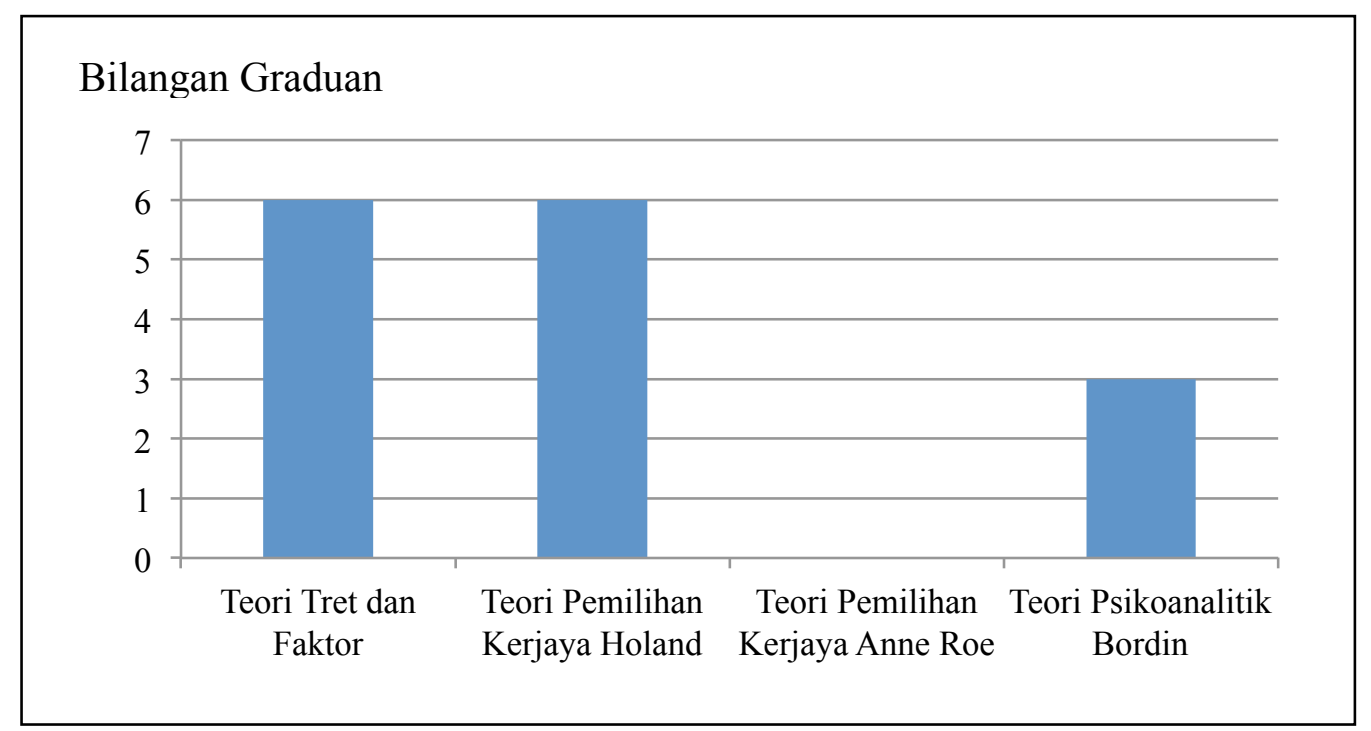

Rajah 2: Bilangan Graduan 2008 Mengikut Teori Pemilihan Kerjaya

\section{Analisis Terhadap Faktor- faktor Kejayaan Dalam Kerjaya Graduan SBC 2008}

Disebalik kerjaya yang dilakukan, setiap orang menginginkan kejayaan yang dicekapi selepas berusaha dan komited dalam satu bidang. Kejayaan dikecapi boleh memberi kepuasan dalam melakukan kerja tanpa memikirkan istilah jemu dan penat. Analisis terhadap faktor- faktor kejayaan dalam kerjaya responden bertujuan untuk melihat ciri- ciri yang penting disebalik kejayaan responden di dalam kerjaya mereka

\section{Ciri- ciri Dalam Mencapai Kejayaan Yang Diinginkan}

Seperti yang dilakukan pada analisis sebelumnya, analisis ini adalah hasil daripada jawapan graduan SBC 2008 yang menjadi responden seramai 15 orang. Berikut merupakan hasil dari pengiraan purata perbezaan skor dan pengelasan skor mengikut skala bagi menunjukkan ciri- ciri yang penting dalam mencapai kejayaan dalam kerjaya responden.

Merujuk kepada Jadual 6, berikut merupakan hasil analisis yang dilakukan bagi mengenal pasti faktorfaktor kejayaan dalam kerjaya graduan. Berdasarkan pembacaan dan kajian literatur yang dilakukan, terdapat 25 ciri- ciri dalam mencapai kejayaan dalam kerjaya. Terdapat 17 ciri- ciri yang sangat penting yang dipilih oleh graduan bagi mencapai kejayaan dalam kerjaya mereka. Bagi memastikan kejayaan dicapai dalam kerjaya graduan menyatakan menjaga tingkah laku, berdisiplin dan mengikut peraturan kerja adalah sangat penting. Selain itu, graduan juga berpendapat menunjukkan komitmen dan komited dalam pekerjaan serta menghormati rakan sekerja dan majikan merupakan ciri- ciri yang sangat penting dalam memperolehi kejayaan dalam kerjaya. Menerima setiap tugasan dengan rela hati 
dan siapkan sebelum atau pada masa yang ditetapkan serta menggunakan komunikasi yang baik dan berkesan juga sangat penting dalam mencapai kejayaan dalam kerjaya graduan.

Selain itu, ciri- ciri yang sangat penting bagi memperolehi kejayaan dalam kerjaya ialah berinisiatif dalam mengatasi masalah yang bakal atau telah berlaku serta memahami cara kerja yang dipraktikkan oleh organisasi. Ciri- ciri yang sangat penting juga melibatkan penyesuaian diri dengan persekitaran dan budaya tempat kerja serta menjalankan sistem penyimpanan maklumat yang sesuai dengan jenis pekerjaan. Graduan juga perlu berdikari dalam menjalankan tugas yang diberikan dan mematuhi arahan orang atasan atau majikan dalam apa- apa tindakan yang dilakukan. Menerima teguran dengan hati terbuka dan meminta pandangan dari pekerja yang berpengalaman juga merupakan ciri- ciri yang sangat penting dalam memperolehi kejayaan dalam kerjaya. Selain itu juga, graduan berpendapat tubuh badan perlulah sentiasa dalam keadaan sihat dan gunakan kemahiran yang ada untuk membantu keluarga merupakan antara ciri- ciri yang sangat penting dalam memperolehi kejayaan dalam kerjaya mereka.

Jadual 6: Ciri- ciri bagi Mencapai Kejayaan Dalam Kerjaya Graduan 2008 Mengikut Kategori Kepentingan

\begin{tabular}{|c|c|c|}
\hline Jenis Kategori & Ciri - ciri & $\begin{array}{l}\text { Purata } \\
\text { Skor }\end{array}$ \\
\hline \multirow{17}{*}{ Paling Penting } & Menjaga tingkah laku, berdisiplin dan mengikut peraturan & 4.667 \\
\hline & Menunjukkan komitmen dan komited dalam pekerjaan & 4.667 \\
\hline & Menghormati rakan sekerja dan majikan & 4.600 \\
\hline & $\begin{array}{l}\text { Menerima setiap tugasan dengan rela dan siapkan sebelum/ pada } \\
\text { masa yang ditetapkan }\end{array}$ & 4.600 \\
\hline & Menggunakan komunikasi yang berkesan & 4.600 \\
\hline & Berinisiatif dalam mengatasi masalah yang bakal/ telah berlaku & 4.533 \\
\hline & Memahami cara kerja organisasi & 4.533 \\
\hline & Menyesuaikan diri dengan persekitaran dan budaya tempat kerja & 4.467 \\
\hline & Mengikut visi dan misi yang digariskan oleh syarikat & 4.467 \\
\hline & Memahami bentuk pengurusan maklumat organisasi & 4.467 \\
\hline & $\begin{array}{l}\text { Menjalankan sistem penyimpanan maklumat yang sesuai dengan } \\
\text { jenis pekerjaan }\end{array}$ & 4.467 \\
\hline & Berdikari dalam menjalankan tugasan yang diberikan & 4.400 \\
\hline & Mengikut dan menerima arahan dari majikan atau orang atasan & 4.400 \\
\hline & Menerima teguran dengan hati yang terbuka & 4.400 \\
\hline & Meminta pandangan dari pekerja yang berpengalaman & 4.400 \\
\hline & Sentiasa dalam keadaan yang sihat dan cergas sewaktu bekerja & 4.333 \\
\hline & Menggunakan kemahiran yang ada dalam membantu keluarga & 4.267 \\
\hline \multirow[t]{6}{*}{ Penting } & Memastikan kawasan kerja sentiasa selesa, kemas dan bersih & 4.200 \\
\hline & $\begin{array}{l}\text { Penggunaan bahasa/ dialek yang sesuai ketika bersama rakan } \\
\text { sekerja atau majikan/ orang atasan }\end{array}$ & 4.133 \\
\hline & Meminta restu ibu bapa & 4.067 \\
\hline & Memakai pakaian yang sesuai ke tempat kerja & 4.000 \\
\hline & Berbuat baik/ rapat dengan orang atasan/majikan & 4.000 \\
\hline & Menerima/ meminta nasihat tentang kerjaya dari keluarga & 3.933 \\
\hline Tidak Pasti & -Tiada- & \\
\hline Tidak Penting & $\begin{array}{l}\text { Bekerja lebih masa untuk membantu keluarga dalam bentuk } \\
\text { kewangan }\end{array}$ & 3.333 \\
\hline $\begin{array}{l}\text { Paling Tidak } \\
\text { Penting }\end{array}$ & $\begin{array}{l}\text { Membantu ahli keluarga untuk mendapatkan pekerjaan dalam } \\
\text { organisasi }\end{array}$ & 2.467 \\
\hline
\end{tabular}

Manakala, terdapat 6 ciri- ciri yang difikirkan masih penting oleh graduan bagi mencapai kejayaan dalam kerjaya mereka. Antaranya memastikan kawasan kerja sentiasa selesa, kemas dan bersih serta menggunakan bahasa atau dialek yang sesuai dalam berkomunikasi dengan rakan- rakan sekerja, majikan atau orang atasan. Selain itu, restu ibu bapa dan menerima atau meminta nasihat daripada 
mereka juga penting bagi mencapai kejayaan. Memakai pakaian yang sesuai dengan pekerjaan dan sentiasa berbuat baik atau rapat dengan orang atasan atau majikan juga merupakan ciri- ciri penting bagi kejayaan dalam kerjaya graduan. Dalam analisis bahagian ini, tiada ciri- ciri yang tidak pasti bagi mencapai kejayaan dalam kerjaya yang dinyatakan oleh graduan. Selain itu, pendapat dari graduan menyatakan bekerja lebih masa semata- mata untuk membantu keluarga merupakan ciri- ciri yang tidak penting bagi mencapai kejayaan. Manakala, membantu ahli keluarga untuk mendapatkan pekerjaan dalam organisasi pula amat tidak penting dalam menentukan kejayaan dalam kerjaya mereka.

\section{Kepuasan Dalam Kerjaya Yang Diceburi Sekarang}

Kepuasan adalah sesuatu yang penting dalam kerjaya bagi menambah baik potensi kejayaan sekali gus memperbaiki kelemahan dan mempertingkatkan daya usaha dan pengalaman. Setelah melakukan analisis bagi soalan ini, kesemua 15 graduan SBC 2008 amat berpuas hati dengan kerjaya yang mereka lakukan sekarang iaitu $100 \%$ berpuas hati dengan tahap pencapain mereka dalam kerjaya yang dilakukan.

\section{Punca Kegagalan Seseorang Dalam Kerjaya}

Kegagalan dalan pekerjaan amat ditakuti oleh seluruh pekerja kerana pekerjaan merupakan sumber rezeki dan tempat pekerja mencari pengalaman. Dalam analisis yang dilakukan, kebanyakkan daripada responden telah menyenaraikan sebab- sebab utama yang sama gagalnya seseorang pekerja. Kegagalan seseorang pekerja adalah berdasarkan empat faktor utama iaitu disiplin, komitmen, komited dan sikap dalam melakukan sesuatu pekerjaan. Majoriti yang bekerja dalam sektor pembinaan menyatakan bahawa sektor ini amat mencabar dan setiap individu perlu bersifat lebih terbuka dalam melakukan sesuatu tindakan.

\section{Profil Responden - Graduan Sarjana Muda Sains Pembinaan (SBC) 2007}

Bagi graduan 2007, sejumlah 15 borang soal selidik telah diterima dan dianalisis. Kesemua responden ini merupakan Graduan Ijazah Sarjana Muda Sains Pembinaan yang menerima penganugerahan masing- masing pada tahun 2007. Dalam analisis yang dilakukan terhadap pengalaman bekerja graduan 2007, tiada responden yang bekerja kurang dari lima tahun. Seramai 14 orang responden $(93 \%)$ telah bekerja antara lima tahun sehingga tujuh tahun. Manakala baki 7 peratus responden telah bekerja lebih dari tujuh tahun. Dari hasil penganalisaan, graduan yang bekerja lebih dari 7 tahun adalah kerana responden pernah bekerja selepas menamatkan pengajian diploma dan sebelum melanjutkan pelajaran di peringkat sarjana muda. Jadual 7 , menunjukkan jantina dan status responden. Secara keseluruhan, terdapat 47 peratus responden lelaki yang mewakili 7 orang dan 53 peratus responden perempuan yang mewakili 8 orang, di mana 13 peratus responden adalah bujang yang mewakili 2 orang manakala 87 peratus responden lagi telah berkahwin yang mewakili seramai 13 orang.

Jadual 7: Maklumat Diri Graduan 2007 Berdasarkan Pengalaman Bekerja

\begin{tabular}{|c|c|c|c|c|c|c|c|c|c|c|}
\hline \multirow[t]{3}{*}{ Pengalaman Bekerja } & \multirow{2}{*}{\multicolumn{2}{|c|}{$\begin{array}{l}\text { Jumlah } \\
\text { Responden }\end{array}$}} & \multicolumn{4}{|c|}{ Jantina } & \multicolumn{4}{|c|}{ Status } \\
\hline & & & \multicolumn{2}{|c|}{ Lelaki } & \multicolumn{2}{|c|}{ Perempuan } & \multicolumn{2}{|c|}{ Bujang } & \multicolumn{2}{|c|}{ Berkahwin } \\
\hline & Bil. & $\%$ & Bil. & $\%$ & Bil. & $\%$ & Bil. & $\%$ & Bil. & $\%$ \\
\hline Kurang Dari & 0 & $0 \%$ & 0 & $0 \%$ & 0 & $0 \%$ & 0 & $0 \%$ & 0 & $0 \%$ \\
\hline 5 Tahun Sehingga 7 Tahun & 14 & $93 \%$ & 7 & $47 \%$ & 7 & $46 \%$ & 2 & $13 \%$ & 12 & $80 \%$ \\
\hline Lebih Dari 7 Tahun & 1 & $7 \%$ & 0 & $0 \%$ & 1 & $7 \%$ & 0 & $0 \%$ & 1 & $7 \%$ \\
\hline Jumlah & 15 & $100 \%$ & 7 & $47 \%$ & 8 & $53 \%$ & 2 & $13 \%$ & 13 & $87 \%$ \\
\hline
\end{tabular}

Dalam Jadual 8 dibawah, daripada jumlah keseluruhan 15 orang responden dari graduan 2007, sebanyak 87 peratus responden merupakan berbangsa Melayu, 7 peratus responden adalah berbangsa Cina manakala baki 6 peratus responden merupakan bangsa India. 
Jadual 8 Pembahagian Graduan 2007 Mengikut Bangsa

\begin{tabular}{|c|c|c|c|c|c|c|c|c|}
\hline \multirow[t]{3}{*}{ Pengalaman Bekerja } & \multirow{2}{*}{\multicolumn{2}{|c|}{$\begin{array}{l}\text { Jumlah } \\
\text { Responden }\end{array}$}} & \multicolumn{6}{|c|}{ Bangsa } \\
\hline & & & \multicolumn{2}{|c|}{ Melayu } & \multicolumn{2}{|c|}{ Cina } & \multicolumn{2}{|c|}{ India } \\
\hline & Bil. & $\%$ & Bil. & $\%$ & Bil. & $\%$ & Bil. & $\%$ \\
\hline Kurang Dari 5 Tahun & 0 & $0 \%$ & 0 & $0 \%$ & 0 & $0 \%$ & 0 & $0 \%$ \\
\hline 5 Tahun Sehingga 7 Tahun & 14 & $93 \%$ & 12 & $80 \%$ & 1 & $7 \%$ & 1 & $6 \%$ \\
\hline Lebih Dari 7 Tahun & 1 & $7 \%$ & 1 & $7 \%$ & 0 & $0 \%$ & 0 & $0 \%$ \\
\hline Jumlah & 15 & $100 \%$ & 13 & $87 \%$ & 1 & $7 \%$ & 1 & $6 \%$ \\
\hline
\end{tabular}

\section{Analisis Laluan Kerjaya Graduan SBC 2007}

Analisis yang telah dijalankan ke atas graduan 2007 mendapati kesemua 15 responden masih bekerja sehingga 2013. Daripada jumlah tersebut seramai 14 orang responden sedang bekerja dengan menggunakan kelulusan Sarjana Muda Sains Pembinaan dan hanya seorang graduan sahaja yang bekerja menggunakan kelulusan Sarjana (Master)

\section{Analisis Terhadap Faktor-faktor Mempengaruhi Pemilihan Kerjaya Graduan 2007}

Jadual 9 di bawah merupakan hasil dari pengiraan purata perbezaan skor dan pengelasan skor mengikut skala bagi mengkategorikan faktor- faktor pemilihan kerjaya bagi graduan 2007:

Jadual 9: Faktor- faktor yang Mempengaruhi Pemilihan Kerjaya Graduan 2007 Mengikut Kategori Mempengaruhi

\begin{tabular}{|c|c|c|}
\hline Kategori & Faktor- faktor & Purata Skor \\
\hline Paling & Kerjaya yang stabil serta menjamin masa hadapan & 4.667 \\
\hline \multirow[t]{7}{*}{ Mempengaruhi } & Berpengalaman dalam bidang yang sama & 4.400 \\
\hline & Pendapatan yang berpatutan untuk membantu keluarga & 4.400 \\
\hline & Mempunyai kemahiran tertentu dalam kerjaya tersebut & 4.267 \\
\hline & Berkelulusan akademik seperti yang dinyatakan di dalam iklan & 4.267 \\
\hline & $\begin{array}{l}\text { Mempunyai kemahiran komunikasi yang baik, penting dalam } \\
\text { kerjaya tersebut }\end{array}$ & 4.267 \\
\hline & Struktur organisasi yang teratur & 4.267 \\
\hline & Mempunyai minat terhadap kerjaya & 4.267 \\
\hline \multirow[t]{8}{*}{ Mempengaruhi } & Faedah kewangan seperti bonus dan elaun & 4.000 \\
\hline & Tempat kerja yang mengamalkan nilai etika yang tinggi & 3.933 \\
\hline & Kerja yang mudah mencapai kepuasan dalam pekerjaan & 3.933 \\
\hline & Waktu kerja yang fleksibel & 3.867 \\
\hline & $\begin{array}{l}\text { Kemudahan di tempat kerja seperti komputer, mesin faks dan } \\
\text { internet }\end{array}$ & 3.800 \\
\hline & Perbelanjaan dan perjalanan ke tempat kerja & 3.733 \\
\hline & Keadaan tempat kerja yang bersih dan selesa & 3.733 \\
\hline & Mempunyai kemahiran dalam ICT & 3.600 \\
\hline \multirow[t]{4}{*}{ Tidak Pasti } & Kemudahan yang disediakan seperti rumah dan kenderaan & 3.400 \\
\hline & Lokasi tempat kerja & 3.333 \\
\hline & Kerjaya yang tidak rumit dan mudah diselesaikan & 3.200 \\
\hline & Cuti tahunan yang banyak & 3.200 \\
\hline Tidak & Mudah mendapat kenaikkan pangkat & 2.800 \\
\hline Mempengaruhi & Mencari sesuatu kelainan dalam kerjaya antara keluarga & 2.733 \\
\hline Paling & Kerjaya yang menjadi tradisi keluarga & 2.067 \\
\hline Tidak & Keluarga yang mempenyai selok belok dalam sektor tersebut & 1.933 \\
\hline Mempengaruhi & Kehendak ibu bapa & 1.600 \\
\hline
\end{tabular}


Hasil daripada analisis yang dilakukan ke atas faktor-faktor pemilihan kerjaya graduan 2007, penyelidik dapat mengkelaskan graduan mengikut teori- teori pemilihan kerjaya yang terpilih berdasarkan kajian literatur yang dilakukan sebelumnya. Hal ini adalah bertujuan bagi melihat jumlah graduan yang menggunakan teori- teori pemilihan kerjaya tertentu secara sedar mahupun tidak sedar. Rajah dibawah menunjukkan jumlah graduan mengikut teori pemilihan kerjaya yang digunakan.

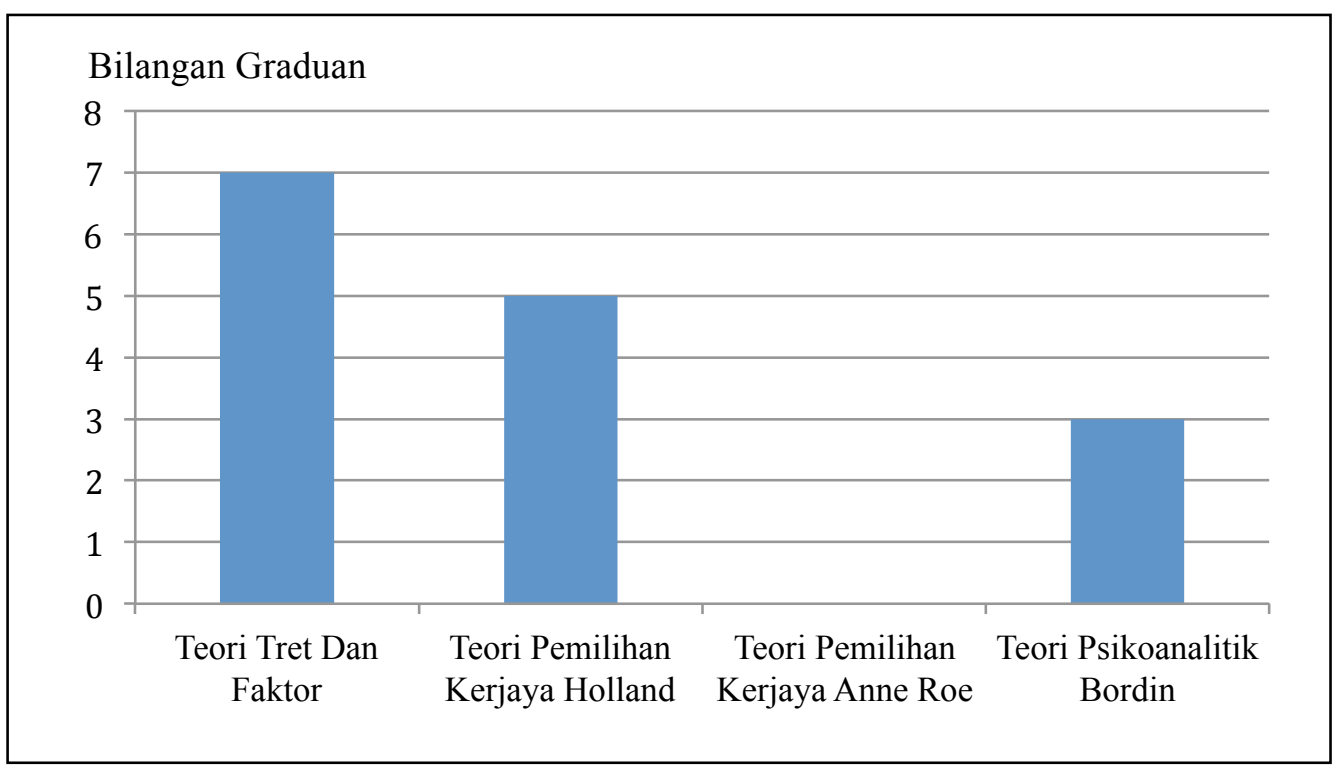

Rajah 3: Bilangan Graduan 2007 Mengikut Setiap Teori Pemilihan Kerjaya

\section{Analisis Terhadap Faktor-faktor Kejayaan Dalam Kerjaya Graduan SBC 2007}

Kejayaan dalam kerjaya merupakan sesuatu perkara yang amat dinanti-nanti oleh graduan setelah bergelar seorang pekerja. Pelbagai ciri-ciri akan mempengaruhi seseorang graduan dalam tempoh mencapai kejayaan yang diinginkan. Cabaran dalam kerjaya juga akan menjadi salah satu ukuran kejayaan seorang graduan yang akan membantu dalam membina pengalaman dan semangat sewaktu bekerja.

\section{Ciri-ciri Dalam Mencapai Kejayaan Yang Diinginkan}

Berdasarkan analisis kajian yang dilakukan, penyelidik mendapati graduan SBC 2007 mempunyai pendapat yang berbeza mengenai faktor- faktor kejayaan mereka dalam kerjaya yang diceburi. Terdapat hanya satu ciri yang paling penting dinyatakan oleh graduan bagi mencapai kejayaan dalam kerjaya mereka iaitu restu ibu bapa. Selain itu, terdapat 11 ciri- ciri yang penting bagi graduan mencapai kejayaan dalam kerjaya mereka antaranya menunjukkan komitmen dan komited dalam pekerjaan serta menjaga tingkah laku, berdisiplin dan mengikut peraturan. Menjalankan sistem maklumat yang sesuai mengikut jenis pekerjaan dan menghormati rakan sekerja dan majikan merupakan ciri- ciri yang penting bagi kejayaan dalam kerjaya graduan. Selain dari itu, menggunakan komunikasi yang baik dan berkesan, memahami bentuk pengurusan maklumat dalam organisasi serta sentiasa dalam keadaan yang sihat dan cergas merupakan antara ciri- ciri penting bagi graduan bagi memperolehi kejayaan dalam kerjaya yang mereka lakukan. Menurut graduan, mengaplikasi kemahiran yang ada bagi membantu keluarga dan memahami cara kerja organisasi juga merupakan ciri- ciri yang penting. Selain itu, mengikut dan menerima arahan dari majikan atau orang atasan dan menerima teguran tersebut dengan hati yang terbuka turut menjadi ciri- ciri yang penting bagi memperolehi kejayaan dalam kerjaya graduan SBC 2007. 
DOI: https://doi.org/10.47405/mjssh.v5i6.422

Jadual 10: Ciri- ciri bagi Mencapai Kejayaan Dalam Kerjaya Graduan 2007 Mengikut Kategori Kepentingan

\begin{tabular}{lll}
\hline Kategori & Ciri- ciri & $\begin{array}{l}\text { Purata } \\
\text { Skor }\end{array}$ \\
\hline Paling Penting & Meminta restu ibu bapa & 4.733 \\
Penting & Menunjukkan komitmen dan komited dalam pekerjaan & 4.467 \\
& Menjaga tingkah laku, berdisiplin dan mengikut peraturan & 4.467 \\
& Menjalankan sistem penyimpanan maklumat yang sesuai dengan & 4.467 \\
& jenis pekerjaan & \\
& Menghormati rakan sekerja dan majikan & 4.400 \\
& Menggunakan komunikasi yang baik dan berkesan & 4.400 \\
& Memahami bentuk pengurusan maklumat dalam organisasi & 4.400 \\
& Sentiasa keadaan yang sihat dan cergas & 4.333 \\
& Menggunakan kemahiran yang ada dalam membantu keluarga & 4.333 \\
& Memahami cara kerja organisasi & 4.333 \\
Tidak Pasti & 4.333 \\
& Mengikut dan menerima arahan dari majikan atau orang atasan & 4.333 \\
& Menerima teguran dengan hati yang terbuka & 4.267 \\
& Menerima/ meminta nasihat tentang kerjaya dari keluarga & 4.267 \\
& Mengikut visi dan misi yang digariskan oleh syarikat & 4.267 \\
& Meminta pandangan dari pekerja yang berpengalaman & 4.200 \\
& Berinisiatif dalam mengatasi masalah yang bakal/ telah berlaku & 4.200 \\
& Menyesuaikan diri dengan persekitaran dan budaya tempat kerja & 4.133 \\
& Memastikan kawasan kerja sentiasa selesa, kemas dan bersih & 4.067 \\
Tidak Penting & Berdikari dalam menjalankan tugas yang diberikan & 4.067 \\
& Menerima setiap tugasan dengan rela dan siapkan sebelum/pada & \\
& masa yang ditetapkan & 4.067 \\
& Berbuat baik/ rapat dengan orang atasan/ majikan & 4.067 \\
& Penggunaan bahasa/ dialek yang sesuai ketika bersama rakan & \\
Tidak Penting & Bekerja atau majikan/ orang atasan & 3.867 \\
& kekerja lebih masa untuk membantu keluarga dalam bentuk & 3.800 \\
& Memakai pakaian yang sesuai ke tempat kerja & 3.667 \\
\hline
\end{tabular}

Manakala, terdapat 6 ciri- ciri yang dikategorikan sebagai tidak pasti. Menerima atau meminta nasihat tentang kerjaya dari keluarga dan mengikut visi dan misi yang digariskan oleh syarikat merupakan antara ciri- ciri yang tidak pasti bagi graduan dalam memperolehi kejayaan. Selain itu, graduan juga berpendapat bahawa meminta pendapat dari rakan sekerja yang berpengalaman dan berinisiatif dalam mengatasi masalah yang bakal atau telah berlaku adalah ciri- ciri yang tidak pasti. Menurut graduan SBC 2007, menyesuaikan diri dengan budaya dan persekiataran tempat kerja serta memastikan kawasan kerja sentiasa selesa kemas dan bersih merupakan ciri- ciri yang mereka tidak pasti bagi memperolehi kejayaan dalam kerjaya mereka. Terdapat 4 ciri- ciri yang tidak penting bagi graduan dalam memperolehi kejayaan dalam kerjaya mereka. Antaranya ialah berdikari dalam sesuatu tugas yang diberikan dan juga menerima setiaptugasan dengan rela dan siapkan sebelum atau pada masa yang ditetapkan.

Selain itu, berbuat baik dengan orang atasan atau majikan juga merupakan ciri yang tidak penting dalam memperolehi kejayaan dalam kerjaya graduan. Graduan juga berpendapat bahawa pengunaan bahasa atau dialek yang sesuai ketika bersama rakan sekerja atau majikan atau orang atasan merupakan ciri yang tidak penting dalam mencapai kejayaan dalam kerjaya yang mereka ceburi. Manakala terdapat 3 ciri- ciri yang paling tidak penting dalam mencapai kejayaan menurut para graduan SBC 2007. Bekerja lebih masa untuk membantu keluarga dalam bentuk kewangan bukan lah antara ciri yang penting bagi graduan memperoleh kejayaan yang diinginkan. Selain itu, memakai pakaian yang sesuai di tempat kerja serta membantu keluarga untuk mendapatkan pekerjaan dalam 
organisasi turut menjadi ciri- ciri yang paling tidak penting bagi memperoleh kejayaan dalam kerjaya mereka.

\section{Kepuasan Dalam Kerjaya Yang Diceburi}

Setelah melakukan analisis bagi soalan ini, kesemua 15 graduan SBC 2007 amat berpuas hati dengan kerjaya yang mereka lakukan sekarang iaitu 100 peratus berpuas hati dengan tahap pencapaian mereka dalam kerjaya yang dilakukan. Terdapat graduan yang menyatakan bahawa apabila masalah dalam pekerjaan dapat diselesaikan, maka kepuasan akan timbul dalam dirinya. Selain itu, graduan juga menyatakan bahawa kepuasan dalam kerjaya bukan sahaja tertumpu kepada kesesuaian dan peluang dalam kerjaya tersebut tetapi lebih kepada minat yang mendalam terhadap kerjaya yang diceburi. Graduan juga turut menyatakan, kepuasan dalam kerjaya akan timbul apabila kerjaya tersebut dapat memenuhi keperluan keluarganya. Terdapat juga graduan yang menyatakan bahawa kepuasan yang dicapai adalah kerana pendapatan yang diterima adalah berpatutan dengan hasil kerja yang dilakukan. Selain itu, graduan turut menyatakan kepuasan dalam kerjaya dapat dirasai setelah sasaran yang dirancang tercapai. Ini kerana menurutnya, setiap kerjaya yang dilakukan tidak lari dari cabaran. Pekerjaan yang dilakukan dapat mempertingkatkan daya usaha dan pengalaman supaya tidak terus berada dalam keadaan yang selesa tetapi sentiasa ke arah yang lebih baik.

\section{Punca Kegagalan Seseorang Dalam Kerjaya}

Dalam analisis yang dilakukan, graduan berpendapat punca kegagalan seseorang dalam kerjaya mereka adalah kerana kurang komitmen dan tidak komited dalam melakukan sesuatu kerja. Selain itu, faktor malas dan tidak mahu belajar serta tiada motivasi diri yang cukup juga menjadi punca kepada kegagalan seseorang. Kurang disiplin dan tiada minat juga dinyatakan oleh graduan yang mencadi punca kegagalan dalam kerjaya seseorang pekerja. Terdapat juga graduan berpendapat bahawa kurang semangat bekerja dalam kumpulan dan tidak boleh menerima teguran juga menjadi salah satu punca kegagalan. Selain itu, graduan juga berpendapat kelemahan dalam mengusasi pengetahuan asas dalam kerjaya yang diceburi, terlalu memilih kerjaya dan tidak memahami keperluan kerjaya tersebut juga menjadikan seorang pekerja itu gagal dalam kerjayanya.

\section{Kesimpulan}

Bagi graduan 2007 dan 2008, faktor-faktor yang paling mempengaruhi pemilihan kerjaya mereka ialah kerjaya yang stabil serta menjamin masa hadapan, struktur organisasi syarikat yang teratur, mempunyai kemahiran komunikasi yang baik yang penting dalam organisasi, mempunyai pengalaman dalam bidang yang sama, mempunyai minat terhadap kerjaya tersebut dan pendapatan yang berpatutan untuk membantu keluarga. Manakala bagi ciri-ciri yang paling penting dalam mencapai kejayaan dalam kerjaya antaranya restu ibu bapa dan menjaga tingkat laku, berdisiplin serta mengikut peraturan. Kesemua graduan yang ditanya tentang kepuasan dalam kerjaya menyatakan meraka puas dengan kerjaya yang diceburi sekarang. Graduan turut berpendapat bahawa antara punca- punca kegagalan seseorang dalam kerjaya adalah atas faktor komitmen, komited, sikap dan semangat.

\section{Rujukan}

Engku Ahmad Zaki Engku Alwi (2007). Mencari Taraf Jihad Dalam Kerjaya. Isnin, 30 April 2007. Berita Harian, New Straits Times (M) Berhad.

Faculty of Built Environment (2011/2012). Academic Guidebook. Universiti Tekonologi Malaysia. Skudai, Graphic Unit, Office of Corporate Affairs.

Kamus Dewan Bahasa Edisi Keempat (2005). Dewan Bahasa dan Pustaka. Kuala Lumpur.

Miriam Grosof \& Hyman Sardy (1985). A Research Primer For The Social And Behavioral Sciences. Academic Press, Inc. Orlando, Florida.

Mohamed Khaled Nordin (2010). Kuasai Ilmu, Nilai dan Kemahiran. 18 Ogos 2010. Utusan Malaysia. Daripada: http://khalednordin.com/?p=696 
Mohamad Izzuan Mohd Ishar \& Fuziah Ismail (2019). Laluan Kerjaya Graduan Sarjana Muda Sains Pembinaan Universiti Teknologi Malaysia. Proceedings of the 1st TVET Chapter 2019. $79-110$.

Mohd Najib Abdul Ghafar (2003). Reka Bentuk Tinjauan Soal Selidik Pendidikan. Universiti Teknologi Malaysia, Penerbit Universiti Teknologi Malaysia.

Mohd. Nazib Md. Samtri (2005). Halatuju Kerjaya dan Pendidikan Graduan Ukur Bahan Universiti Teknologi Malaysia. Kertas Projek (Sarjana Muda Ukur Bahan), Universiti Teknologi Malaysia.

Mohd Yahya Mohamed Ariffin \& Roseliza Murni Ab. Rahman (2002). Melangkah Ke Dunia Pekerjaan. Kuala Lumpur, Utusan Publications \& Distributors Sdn. Bhd.

Norzilawati Abd Halim (2005). Pilih Kursus Potensi Kerjaya. Jumaat, 24 Jun 2005. Berita Harian, New Straits Times (M) Berhad.

Oxford Online Dictionary (2012). Oxford University Press. Oxford.

Rosniza Mohd Taha (2009). Peluang Kerjaya. Isnin, 16 Februari 2009. Berita Harian, New Straits Times (M) Berhad.

Sariha Mohd Ali (2009). Tambah Kemahiran Untuk Tingkat Kerjaya. Isnin, 20 April 2009. Berita Harian, New Straits Times (M) Berhad.

Sidek Mohd Noah (2002). Perkembangan Kerjaya: Teori \& Praktis. Selangor, Penerbit Universiti Putra Malaysia.

Siti Zanariah Sulaiman (2011). Hubungan Faktor Kesedaran Dengan Kematangan Kerjaya Dalam Kalangan Mahasiswa Tahun Satu Universiti Teknologi Malaysia. Thesis Sarjana Pemdidikan (Bimbingan dan Kaunseling), Universiti Teknologi Malaysia.

UTM Skudai (1990). Seminar Peluang dan Masa Depan Kontraktor Kelas Rendah di Negeri Johor. Universiti Teknologi Malaysia.

Utusan Malaysia (2009). Rakyat Malaysia Lebih Utamakan Kerjaya Berbanding Keluarga. Jumaat, 22 Mei 2009. Utusan Malaysia, Utusan Melayu (M) Berhad. 